\title{
Universiteit
}

Leiden

The Netherlands

\section{The roots of African corruption}

Ellis, S.

\section{Citation}

Ellis, S. (2006). The roots of African corruption. Current History, 105(691), 203-208. Retrieved from https://hdl.handle.net/1887/9552

Version: $\quad$ Not Applicable (or Unknown)

License: $\quad$ Leiden University Non-exclusive license

Downloaded from: $\quad$ https://hdl.handle.net/1887/9552

Note: To cite this publication please use the final published version (if applicable). 
"In broad swaths of Africa many types of corrupt practice are not the deviant behavior of a small minority - they are a standard mode of transacting political and financial business."

\title{
The Roots of African Corruption
}

\author{
Stephen Ellis
}

$t$ is easy to imagine how you could smuggle a diamond. A diamond is small enough to be held in the hand, carried in the body, or hidden in the seam of a jacket or the heel of a shoe. It is considerably less easy to imagine how someone smuggles a tanker-full of oil. Yet that is an everyday

\section{CORRUPTION}

Ninth in a series occurrence in Nigeria, one of the world's leading oil producers. Clearly, it can be done only with the collusion, at the very least, of very senior government officials and officers of the armed forces, the navy in particular.

Corruption is notoriously hard to measure or even to define, and therefore it is impossible to say for certain whether corruption in Africa is increasing or whether it is worse than in other places. What can be said is that it has become astonishingly brazen in recent years, with senior officials and even heads of state quite openly flouting their own countries' laws and a range of international diplomatic and legal conventions.

In the early 1990s, officials in Kenya succeeded in forging their own national currency. Senior Kenyan officials also have been implicated in the so-called Goldenberg scandal, named after a front company that was used to defraud the public treasury of some $\$ 600$ million by claiming government subsidies for nonexistent exports of probably nonexistent gold and diamonds. Among those recently recommended for prosecution are a former head of Kenyan intelligence, a former governor of the central bank, and a former head of the treasury. One of the main architects of the scam has testified that he gave the head of state, Daniel arap

Stephen Ellis is a researcher at the African Studies Center in Leiden, the N etherlands. A former director of the International Crisis G roup's Africa program, he is a coauthor of Worlds of Power: Religious Thought and Political Practice in Africa (Oxford University Press, 2004) and The Criminalization of the State in Africa (Indiana U niversity Press, 1999).
Moi, suitcases full of money, and that he "never visited Moi empty-handed."

When Kenyans eventually voted Moi's party out of office in 2002 in favor of a government pledged to ending corruption, the new team used exactly the same technique. Last year, the administration of President M wai Kibaki was exposed by its own anticorruption chief, the courageous John Githongo, as having paid millions of dollars to fictitious companies or to real companies that were inflating invoices for government contracts. This was done with the full knowledge of key ministers who are themselves suspected of pocketing a big share of the proceeds. Githongo reported his findings to President Kibaki. The president has done precisely nothing.

In Liberia, the transitional government that ran the country until the end of 2005 is believed to have presided over the theft of some $\$ 100$ million per year, compared with an annual budget of a mere $\$ 80$ million, even while it was being monitored by a very substantial United $\mathrm{N}$ ations mission. In other words, this was a government that stole more than it put into the state treasury - and this at a time when Liberia is widely recognized as having its last chance to lay the foundation for a decent system of government after 15 years or more of war and mayhem.

These and a distressing number of other examples suggest why, when it comes to graft, some African countries have earned a reputation for excess, and even for being beyond caring what others may think. No doubt this is why the "corruption perceptions index" prepared by the watchdog group Transparency International consistently places African countries among the worst offenders. A grim joke in Nigeria- which for some years was the second most-corrupt nation on the Transparency International list-held that the country had avoided being ranked as the world's most corrupt by bribing Bangladesh to take over the slot. 


\section{THE UN LAW FUL STATE}

N ot only is there no consensus on precisely what corruption is, but some of the more monstrous cases of corruption can also be called by other names. If a head of state bribes soldiers from the army or officers from the intelligence service to murder his personal enemies, this may indeed be corruption, but it is also conspiracy to murder. If, as in the Goldenberg scam, a businessman with excellent links to government officials colludes with them in securing payments for nonexistent services, it is not only corruption, it is also fraud.

Some African heads of state do not limit themselves to demanding kickbacks for awarding state contracts, which is probably the most common form of official corruption, or extending their protection to professional criminals in return for payment. A handful have gone beyond forms of collusion like these to become the main organizers of syndicates that are smuggling drugs, guns, or other illicit goods on a large scale. They bring to this business all the advantages of state sovereignty: diplomatic bags, diplomatic passports, access to central banks for laundering money, exemption from prosecution, and much more.

In situations like this, observers need to ask themselves what precisely they are dealing with. Is it a problem of corrupt practices among public officials? Or is it a case of professional criminals having taken control of a state, and using it simply as a tool of the trade?

Pursuing this line of thought may lead to historical reflections on the difference between a state and a criminal conspiracy. This reflection need not be unduly cynical. The sociologist Charles Tilly has pointed out that the states that emerged in Europe three or four centuries ago did so largely because of their single-mindedness in organizing armies. To do this, they required finance, which in turn involved raising money from their people. Crudely put, early modern states proposed to their subjects a deal no different from a mobster's unrefusable offer: pay us money, and we will protect you; fail to pay us, and we will rob you.

Associated in European history with the rise of strong states with formidable powers of coercion are countervailing struggles for democracy, freedom of speech, and human rights. The law of habeas corpus and the principle of no taxation without representation were not granted by benign rulers out of the goodness of their hearts, but were negotiated after hard-fought contests. States became both leviathans that could crush dissent and the guaran- tors of contracts between rulers and ruled. Those who refused the agreements they offered became rebels or criminals.

In light of this view of Western history, it becomes still less clear what the exact nature of corruption is in Africa, a continent where modern states have other origins and the struggles of rulers and ruled have taken different forms. In Africa today, ordinary people regularly give bribes to obtain the services they should in theory receive from the state for free, or to police officers who shake down travelers as a matter of course. In Kenya it is estimated the average urban resident pays 16 bribes per month. Junior officials in many countries routinely take bribes to compensate themselves for ludicrously small salaries. Politicians raise money corruptly to fund their campaigns. International businessmen collude in these practices to obtain the contracts they want. Corruption becomes a way of life, a mode of business and politics. "It is simple," a West African civil servant once explained, "the government pretends to pay us, and we pretend to work."

\section{STAN DARD PRACTICE}

None of these practices is unknown in the United States, of course. Their particularity in the case of sub-Saharan Africa is not a matter of scale: the biggest African scams are puny in comparison to Enron, the Texas energy corporation that engaged in massive fraud. Rather, it is a question of context. The word "corruption" implies deviation from a norm, a falling away from accepted standards. Hence, when certain types of illicit transactions become normal to the point that people do not bother to hide them, it is not satisfactory simply to label them as "corruption" or even "crime." This is especially so when the people who run the state are themselves the main organizers of such activity. As we have seen, evidence from Nigeria and Kenya suggests that outrageously corrupt practices have become routine at the very heart of government in some of the continent's most important countries.

Even in South Africa, which has the biggest economy in Africa and is generally regarded as the leading power south of the Sahara, there are signs that corruption exists deep inside the institutions of state. In 1998, no fewer than 10,000 of the country's 140,000 police officers were under investigation for bribery, theft, or involvement in organized crime. These figures are related to the fact that South Africa's transition from apartheid in the early 1990s made it temporarily vulnerable to sophisticated pro- 
fessional criminals from other parts of the world, who found it a convenient location both to organize their activities and to launder their profits.

Overall levels of recorded crime in South Africa have declined slightly in recent years, but according to a survey in 2003, petty corruption is now the most common offense after housebreaking. And yet international diplomats and businesspeople continue to see South Africa as one of Africa's few "normal" states-in the sense that it has a functioning government, a central bank and financial institutions that are able to offer a conducive business environment, and a legal system that, creaky though it is, is capable of producing satisfactory and enforceable judgments in commercial disputes.

The observation that corruption is entrenched in such leading countries as Kenya and Nigeria, and that it remains a definite problem even in South Africa, makes it still more disturbing to contemplate what this suggests about the continent's more obviously dysfunctional states, those commonly considered as "failed" or "failing." It is important to recall that even these countries have legal codes, at least on paper. The problem is that the laws in Africa's dysfunctional states are rarely enforced, or only very selectively. Worse, the authorities theoretically responsible for their implementation may themselves break these same laws continuously and routinely.

This is really what Africa's so-called failed states are - not so much places where the state has ceased to exist, but where the formal trappings of statehood serve purposes of strategic deception, rather like the stage-sets in a theater. In one of these countries, you would have to be naïve to believe that the law, the police, or the central bank really fulfills the role in theory allotted to it. The Democratic Republic of Congo, the Central African Republic, GuineaBissau, and dozens of other African states cannot be regarded as functioning according to international norms. But each one nevertheless has an actual, substantive system of politics and governance- not to be confused with the formal system, although the real and the legal are intertwined.

Anyone who wants to live or do business in a failing state needs to learn the real rules. In each case, the actual conventions of economic, political, and even social life will certainly involve patterns of activity regarded by many international observers as corrupt. In broad swaths of Africa many types of corrupt practice are not the deviant behavior of a small minority - they are a standard mode of transacting political and financial business.

\section{THE HISTO RY OF GRAFT}

To understand the real political economy of corruption requires an appreciation of moral repertoires, which inevitably requires making historical inquiries. Situating corruption within a specific historical context suggests that certain illicit practices, even if they are formally outlawed, may be considered morally permissible by large numbers of people in some circumstances. (Americans should know this as well as anyone, after the experience of Prohibition in the 1920s.) The law and popular perceptions of morality do not always coincide in their views.

Probing how people's understandings of particular types of action change over time has been made more difficult by the popularity of the dangerously simplistic "clash of civilizations" theory made famous by Samuel Huntington, which suggests that cultural blocs are rather impervious to change. In reality, cultures are both more complex and more fluid than that. In the case of Africa, an investigation along these lines throws a good deal of light on the phenomenon of "failing" states, showing them to be not only derogations from international models of good governance, but also places shaped by their individual pasts.

A leading historian, John Lonsdale, once made the striking observation that "the most distinctively African contribution to human history could be said to have been precisely the civilized art of living fairly peaceably together not in states." This remark may remind us that it is indeed possible for people to live together in reasonable harmony without modern states-although whether that is possible in the twenty-first century is another question.

It also provides clues to the historical trajectory of various types of transaction that are often classed today as corrupt. In many cases, these activities have historical antecedents in practices deeply rooted in African societies. Examples include the accumulation of political power and social prestige mainly through patronage; an expectation that rich people will redistribute wealth to their family and other dependents; and a long history of "extraver- 
sion"- the habit of seeking external resources to build political power within African societies.

Culture in Africa has long been a political battleground. During colonial times, European officials claimed a right to rule Africa on the grounds that their culture was superior. Europeans knew how to organize the type of literate bureaucracies that are at the heart of modern government, whereas Africans had had little or no prior experience with this kind of rule.

Slightly later, the claims of African national ists that they had a right to govern themselves were often based on a simple inversion of the colonial prejudice that Africans were unfit for self-government for cultural reasons. African intellectuals could reply that Africa, like every other continent, had its own genius that should be celebrated rather than being a source of embarrassment. After the establishment of the United N ations and a world order based on a system of sovereign states, African leaders could also riposte that every nation in any case had a right to sovereignty.

M ore than 40 years after most African countries acquired sovereign status, these cultural disputes still resonate. Indeed, so politicized does the concept of culture remain with regard to Africa that the mere mention of it risks causing immediate misunderstanding. Of course, observing that a practice has historical roots-in other words, that roughly similar things have occurred previously-does not automatically make it acceptable in our own times. European and American histories are full of examples of historically existing practices that were once considered legitimate but are now seen as distasteful, unrespectable, or illegal. It does not require more than a few moments' reflection to come up with examples. The same should be true of Africawere it not that Africa is so often thought by both its admirers and its detractors to exist in a timeless present of African authenticity.

Some practices considered as corrupt occupy a prominent place in such a schema, and corrupt politicians are not above invoking an imagined authenticity to excuse their behavior. According to the Liberian writer Emmanuel Dolo, people who have served as state officials are expected by their own families to enrich themselves through corruption. Otherwise, he writes, they are accused of failing to do what he calls "the cultural thing": to steal money from the national treasury, an action they may justify on cultural grounds.

In short, corruption has deep roots. If we are to understand it and various related phenomena, including state failure, it is urgent to investigate what has happened over time. In Africa's case, the matters to be considered include a history of power organized on a basis rather different from that in Europe or N orth America. A moment in Africa's history that is particularly relevant for the present discussion was the imposition in colonial times of territorial, bureaucratically governed states that aspired to establish the rule of law.

\section{THE RULE OF LAW}

At this point, it should be made clear what is meant by the establishment of the rule of law in colonial times. Emphatically, this does not mean that colonial government was a just order. It is no more and no less than the observation that colonial government was based on the idea that a centralized state apparatus should be responsible for promulgating a code of laws and associated rules, usually in written form, that have a binding force on society and even on the state itself. This, we may note in passing, makes thinkable the idea of a state crime.

Nor does the colonial establishment of the rule of law mean that public life has been governed ever since by the consistent application of written laws. The point is that from colonial times, and up until today, African countries are in theory governed by the consistent application of written laws. This point is important in part because it allows African politicians and power brokers and their foreign partners or collaborators to manipulate the gap between theory and reality to their advantage.

The preceding observation on the rule of law should also not be taken to suggest that African societies before colonial times were chaotic because they lacked the rule of law. In Africa's case, European colonial officials and a couple of generations of anthropologists tried to identify the authentic rules of African societies in the form of so-called customary law or tradition that they described in ethnographies. It has emerged, however, that the characteristic colonial view of custom or tradition in Africa as a static, codified corpus was not al together accurate. It implied that African societies had been frozen in time and ruled by unchanging custom, but there is every reason to doubt that this was ever so.

What we call "tradition" in African societies before colonial times was not so much a body of rules as a way of justifying change. Justice was not in reality dispensed by the application of a fixed code of traditional laws. It was the prerogative, 
rather, of a ruler acting in accordance with whatever could be represented as tradition. In almost every case, the correct application of "tradition" was inextricable from spiritual beliefs articulated by ritual experts or priests. The latter thus in effect had a role as guarantors of constitutional checks and balances on a ruler, since they could legitimize or disqualify a ruler's actions by pronouncing them as traditional and, therefore, just.

It was precisely because law in precolonial African societies often turned on individual actions and not on a fixed code- and rules were indistinguishable from rituals- that it was unsuitable for European purposes in the late nineteenth century. The globalization of the belle époque, the period that ended in 1914, produced a new breed of bankers and businessmen prepared to loan or invest money anywhere in the world. Large Western corporations found it inconvenient to do business with the ever-shifting population of African kings and big men. Diplomats and bankers increasingly needed a world governed by rules that were enforceable by institutions. They wanted to see Westernstyle jurisdictions with fixed boundaries established everywhere, opening the whole world to business. Where public authorities of this type did not exist, they had to be encouraged.

In Africa, the establishment of colonial territories fulfilled this need. Bankers could lend money to colonial governments that, unlike individual big men, would guarantee the security of a loan over long periods. Investors could seriously contemplate putting money into mines and railways, safe in the knowledge that these assets were located in a specific territory that was party to international legal conventions. These are the conditions necessary for capital ist investment and production.

\section{IN SEARCH OF AUTHENTICITY}

Colonialism endowed Africa with legalbureaucratic government in the many places where nothing fitting this description existed before, and it strengthened the legal and bureaucratic elements in cases where these al ready existed, such as in areas ruled by Muslim sultans. Today, some analysts see this form of government as a Western transplant that, being imposed from outside, never really took root in the African soil or coexisted with the supposedly authentic African way of doing things. This is a romantic point of view; it is also inaccurate.
It is true that every European colonial power did indeed set up a centralized administration in each colony and, to greater or lesser extent, incorporated African rulers in systems of indirect rule. It is now clear that in most cases this involved freezing many of the dynamic processes of local government and, also in many cases, permitted local rulers to dispense with many of the more subtle checks and balances that had traditionally operated, producing what the African scholar Mahmood Mamdani refers to as "decentralized despotisms." But, however cruel, none of this was an assault on African authenticity, a figment of more recent imagination. The originators of authenticity were intellectuals of the colonial period, both African and foreign. The leading political exponent of the concept was Mobutu Sese Seko, the infamously corrupt dictator of Zaïre.

The institutions of legal-bureaucratic government, introduced in most of Africa by colonial rule, are now being hollowed out to produce the façade states that we witness today. This process, often labeled "state failure," is certainly a cause of reduced efficiency in governance. From a politician's point of view, however, it offers increased opportunity to exploit a gap between two measures of reality.

On the one hand is a legal view, defined by national and international law and norms, the basis on which formal diplomatic relations are conducted. On the other hand is the reality of political bargains made between a leader in Africa and those whom he (very rarely she) seeks to represent, include, or assuage, paying particular attention to sectors where capital is produced and reproduced. It is because of the resulting gap between appearance and substance that Northwestern University professor William Reno refers to the existence of a "shadow state" in Africa, a rather imperfect comparison inasmuch as it is the shadow in the metaphor that actually contains most of the substance.

The creation of political capital out of the gap between legal and social reality, al ready perceptible in colonial times, has increased in importance since the 1970 s primarily because of the lack of resources available to the official state apparatus. It is here that the hollowed-out institutions of an African state may become part of wider circuits of deception used by international operators who for one reason or another wish to hide their activities behind a screen of formality and law. These include 
powerful secret services, money launderers, offshore bankers, corporate lawyers, sanctions busters, drug traffickers, arms smugglers, and others.

Ten years ago, I published an article in the journal African Affairs showing in detail how this can work in the case of one small country, the Seychelles. There, in the 1980s, I talian money-launderers with connections to the mafia and to Italian political parties made common cause with drug traders, American covert warriors, South African sanctions busters, and Middle Eastern political fixers, all under cover of a sovereign state- in fact, one with a relatively decent reputation for what is nowadays called "good governance." In the process the Seychelles became one of the few African states to become literally criminal, in the sense of drafting laws designed to evade both its own and international legislation.

\section{CONFIDENCE AND CON MEN}

In what many Africans think of as happier times, there were examples of politicians who, while being massively corrupt, were nevertheless able to use the possibilities offered by their strategic situation and historical legacy in the service of political projects of general interest. A good example is Félix Houphouët-Boigny, president of I vory Coast from 1960 to 1993, who for some two decades oversaw what was known as "the Ivorian miracle," a period of spectacular economic growth and development. Yet Houphouët-Boigny also diverted state resources on a huge scale, using them, for example, to build an imitation of the Vatican's St. Peter's basilica in his home village. He boasted openly about his Swiss bank accounts.

René Amany, a former head of Ivory Coast's cocoa marketing board, attempted to explain the paradox - a corrupt president who governed with conspicuous success- when he recalled nostalgically in a 2004 newspaper interview how Houphouët-Boigny "used money as a means of advancing his political project, not politics as a way of making money."

The corrupt use of a public position to make money, which is then invested in political activities, has also been noted in regard to Nigeria. Writing in the May 2005 issue of Current History, the Nigerian author Ike Okonta described how politics there is "itself a struggle for control of the country's oil largesse, which, once secured in the form of loot, is used to further and consolidate political ends. In this struggle, the state and the means of violence at its disposal are the ultimate spoils."
It is interesting to speculate why the corruption practiced in Ivory Coast during the 1960s and 1970 s could be part of an internationally acclaimed political and economic success story, whereas twenty-first century Nigeria is widely regarded as a potential giant tragically handicapped by corruption. The essential difference between the two cases seems to lie not so much in the existence of corruption-present in both cases-as in the political uses to which it is put. To be successful, any political project has to inspire its supporters with genuine hope and confidence. These are qualities in short supply in Africa since the late 1970s, when the bright vision of progress turned dim in so many of the continent's countries.

Arguably, it is the loss of hope and confidence that makes corruption the scourge it is today. Africans keep an estimated $\$ 150$ billion of capital offshore, money that could be used to develop the continent if its owners had the confidence to invest at home. Seventy thousand highly qualified Africans leave their continent annually, excluding students going abroad to study. Across much of Africa, a getrich-quick and enjoy-it-while-you-can mentality prevails - an attitude fatal to stability, prosperity, and long-term investment.

Africa in recent decades has become poorer, which is an important incentive to corruption. But perhaps more important, it has lost faith in the various projects of modernization and development that promised Africans a better life in the mid-twentieth century. Many mistook the outward signs of material progress for the substance of development, at a time when politicians in need of funds could milk cold war rival ries. The disastrous economic and political decline of the past 30 years has left Africans correspondingly shocked and disillusioned. Here too lie some of the roots of today's corruption, as people grasp at anything that will help them survive the next day, month, or year in a world that seems empty of longer-term hope.

Those states with something to sell- especially oil-risk becoming what have been called "successful failed states," places that show all the symptoms of failure but that are able to continue indefinitely to the benefit of a corrupt ruling clique and its friends overseas. According to the us N ational Intelligence Council, "many African leaders believe that the international economy is still rigged so that Africans will never prosper." As long as this mood prevails, corruption in Africa will continue. 